\title{
EFFECTS OF EXTRACORPOREAL IRRADIATION OF BLOOD AND IMMPR ON HOMOTRANSPLANTATION
}

by

A. D. Chanana, E. P. Cronk1te, M. L. Greenberg, D. D. Joel,

L. M. Schiffer, Hp. Schnappauf, and P. A. Stryckmane

Medicel Research Center

Brookhaven National Laboratory

Upton, New York

\section{LEGAL NOTICE}

\begin{abstract}
account of Government sponsored work. Neither the United This report was preparsion, nor any person acting on behalf of the Cow with respect to the accuStates, nor the Commarranty or representation, expressed or

A. Makes any warranter usefulness of the information contained in this report may not infringe

racy, completenestion, apparatus, method, or process discormation privately owned rights; or

B. Assuttes auy liabilities with respect, or process discluned in this rem includes any emuse of any information, apparatus, moting on behalf of the Commission"

As used in the above, commission, or employeo of such contractor, to thetor prepares, ployee or contractor of such employee or contractor or the any information pursuant

disseminates, or provides access to, went with such contractor.

with the Commission,
\end{abstract}

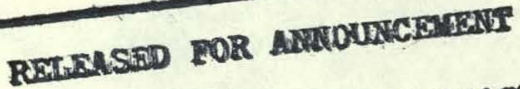
IN MUGLER SCIDUCES ABSTBACTS
BNL 9801

CONf-6.5/208-1 


\section{DISCLAIMER}

This report was prepared as an account of work sponsored by an agency of the United States Government. Neither the United States Government nor any agency Thereof, nor any of their employees, makes any warranty, express or implied, or assumes any legal liability or responsibility for the accuracy, completeness, or usefulness of any information, apparatus, product, or process disclosed, or represents that its use would not infringe privately owned rights. Reference herein to any specific commercial product, process, or service by trade name, trademark, manufacturer, or otherwise does not necessarily constitute or imply its endorsement, recommendation, or favoring by the United States Government or any agency thereof. The views and opinions of authors expressed herein do not necessarily state or reflect those of the United States Government or any agency thereof. 


\section{DISCLAIMER}

Portions of this document may be illegible in electronic image products. Images are produced from the best available original document. 


\section{INIRODUCIION}

- Extenclve Investigations have been carried cut to determine the role of the omell lyuphocyte in the procens of homograft reject10a. Such Investigatione have included study of the reaction in the regional lymph nodes $(1-4)$, the cellular reaction at the olte of transplantation $(5-9)$, and the transfer of traneplantation lmount ty by lymphold calle (10-11). Etudioo on antmale In which normal dẹvelopment of lymphold thesue has been provented (12), smell lyophocytee removed from the anlmal (13), or lymphocytes destroyed by meane of ant-1yaphocyte aerum (14) have ylelded c1rcumstantial evidence regarding the role of the lymphocyte in homograft rejection. Evidence regarding the role of a humoral antibody in firat set akin homograft rejection 1 sontroveralal (15-17).

A state of Imonologic deficlency can be achieved by lyuphocyte depletion, but the methods used to deprese the lymphold immune oystem, lacluding irradiation (18) and cytotoxic druge $(19,20)$, suffer fron the lack of ealectivity. This results In Indiscrimanate demge to all rapldiy dividing celle. Including those of bone marron and Intestinal mucose.

Bxtensive research is belng conducted to discover ways in which belective depreselon of lymphold calle can be achleved. The techniquee that have been tried laclude lrradiation of lymphold tisoue (21), chronic dratnage of thorac1c duct $(13,22,23)$, edministration of ant1lymphocyte eerum (14) and attempts at selective chealcal depression of lyuphocytes (24).

It has been shown that Imunologically competent amall Iymphocytes are constantly rectreuleting through the blood (25). In view of this recircuiation, it 1o perhape not unreasonable to divert a portion of the blood stream through on extracorporeal shupt in order to destroy these relatively 
radiosensitive lymphocytes ln a sultable radietion fleld. Procedures for extracorporeal lrradiation of blood (BCIB) and lymph (BCIL) were perfected In cur laboratory. Although the orlginal description of ouch o procedure dates back to 1939 (26), It lo only recently that the peocedure has been effectively uned. To date cronkite and his colleagues have described the production of prolonged and austalned lymphopenta wth ECIB (27), the wathematical considerations of the dose dietribution to the blood (28), the comblned effect of thoracle duct drainage and extracorporeal irradiation of blood upon the concentration of lymphocytes in the lyoph and blood (29), the hlatologie plcture of lymphoretlcular tlague after prolonged extracorporeal Irradietion of the blood (30), the conetruction and operation of ${ }^{60}$ Co Irradietor (31), the Influence of varylag dose and ropetitive short seselone of extracorporeal irradiation of blood upon the production of 1ymphopenta (32), the tolerance of red cells to radiation (33), and semipermenent arterio-venous and thorec1c duct shunts in calves (34). Th1e commication deals with the influence of ECIB and ECIL upoa the stin homograft rejection procese in calves and discusses the role of Immenologically activated small lymphocytes in this procese (35). MATERTALS AND METHODS

A. Skln Grafte: The technique, along with the histological and clinical observetions, has been deseribed in detall elewhore (36). Our method 18 a ellght modiflcation of the technique of Anderson et al. (37). Full thickness plnch grafts are removed from the dorwu of the ear end grafted elther on to the withers (anter1or grafte), or posterlor to the 11lac crest (posterlor grefte). Unlese specificelly defined, the word okin graft means anterlor graft. Autografts for couparison are et1lized 
In every case. Blopeles for hlstological otudles are taken at regular intervals. The rejection time for akin homografte in untreated animals is from 8 to 10 days. The criterla for graft rejection are edem, hardendag, d1ecoloration and seperation of graft and host marglne. Actual separation of graft from hoot bed is not taken intoconsideration as this varies conB1dorably from anlmal to animal.

- B. Irradietor: A 11000 curle ${ }^{60}$ co irradiator has been used. The Irradiation coll 1. wound around the source. The tranelt dose to eleinents of lymph or blood depends upos the doee rate of the source, the volume in the radiation coll and the flon rate. Flow rate of the blood is measured by infecting a bubble of alr at the axterial and and noting the time it takes to arrive at the venous and. Iymph is intermittently pumped through the Irradiation coll at a flxed rate.

C. Arterlo-Venous (A-V) and Thoracte Duct Bhunte: The ohunte, wheh have been daccribed in datall eleewhere (34), conotst of Teflon cennulae and Sllastlc cublng. 1 For BCIB, A-V shunts are used which function for several weeks. Whenever BCIB 1o desired, the carot1d-Jugular ehunt is connected to the Irrediation coll, and the blood circulates around the 1rradiation source because of differences in arterlal and venous preseures. Beparinleation 10 used during ECIB in order to prevent the blood from clotting in the 1008 Irradiation co11. The thoracte duct is canmulated in the neck uetag omiller alzed Stlastlc and Teflon tubing, and lymph is returned yit the left inforior cervical veln. These shunte also function for eoveral weoke. Lyaph is collected by gravity and returned by pump to the enima ${ }^{2}$. The detalla of the technlque have been desertbed elsewhere (38). The lymph reservolr 10 continually heparialzed. Lymph has been treated In three ways: 1) BCIL, 
2) Centrifugation of 1 Japh and return of cell-2ree 1gaph to the andmats (for thte purpose an IRC PR-2 refrigerated contrifuge equipped with a

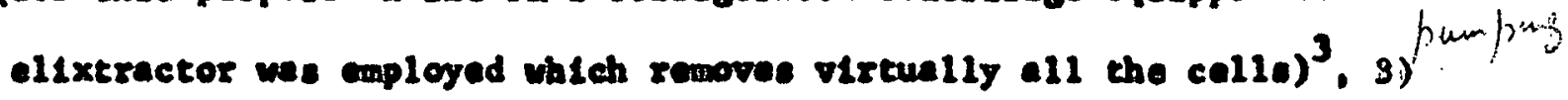
of untracted lyaph to the rumen throuch a Foley catheter ruminostomy. Flgures 1 and 2 deplet the general arrangemante for RCD and for proparation of cell-tree lyuph reopectively.

D. Antelotes: Ponte1111n and stroptomgela are adnlatotered I.K. for five daye after shunt eurgery. Canmulee tracke are fluched out delly with 7-8 ml of eallne contalnding 20 mgm of Terranyeln.

B. Antmig: Fifty-two calvas ranglng in walght from 175 to 712 pounds häve been used. Blghtean calves sorved ae non-treated comparioon anlmale, 25 celvas recelved BCIB, 5 calves recelved ECIL, 2 celves had cantrifugation of lyruph, 1 celf recelved RCIL and centrifugetien of lyuph, and 1 calf had lymph pumped to the rumen...

\section{RBSULTS:}

A. BCIB: (Table 1) Varying schedules and greded erapest dosen of ECIB were tried. S1x calves (the upper part of 818. 3) recelved continuous BCIB for 24 houre, each and okfn honografta ware applled flve dayo lacar. Iranett doses ranged from 15 to 60 rade, and the number of blood volumes Irradlatad rangen from 90-240. The avarage pretreatmont sund1 lymphocyte count vas $2600 / \mathrm{mm}^{3}$. It dropped to $500 / \mathrm{mm}^{3}$ at the termlnation of BCIs and rose to $1800 /$ men $^{3}$ ten days later. Avarage homograft aurvival in thls gxoup was 10 daye.

Three anlmals recelved ropetselve pregraft BCIB. Reoulte in one of

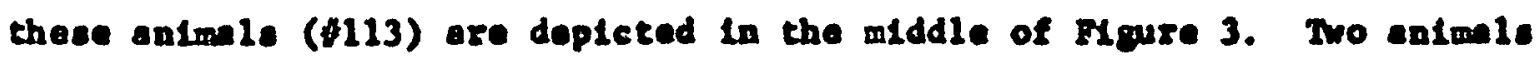
recelved tranat dose of 50 rede each, and 325 and 160 blood volumes 
were 1rradiated. The duration of BCIB was 98 and 112 hours opread over 13 and 19 daya reopectively. The avarage pretreatment emall 1ymphocyte count was $4100 / \mathrm{mm}^{3}$ wh1ch dropped to $200 / \mathrm{mm}^{3}$ at the termination of ECIB and ranged from 100 to $500 / \mathrm{mm}^{3}$ during the next 15 daye. Skin homografts which were epplied at the cermination of BCIB ourvived for (1) 11 and 14 days respectively while in non-treated twino of these animels survival time was 9 and 10 days respectively. In the third animal, the transit dose varted from 10 to 1000 rads, and 210 blood volumes were irredlated during 114 hours apeead over 57 days. The om 11 lymphocyte count dropped from $4000 / \mathrm{mm}^{3}$ to $700 / \mathrm{mm}^{3}$ at the terminetion of BCIB at which time okln homografte wore applled. Skln homografte aurvived for 13 daye, and at that time emall lymphocytes hed risen to a level of $1000 / \mathrm{mm}^{3}$.

A group of flve antmols recelved pre- and post-graft, repet1tive ECIB. Transt doses in th1. group ranged from 215 to 800 rade, and the number of blood volumes irrodiated ranged from 122 to 547 . The duration of ECIB veried froun 54-118 hours apread over parlods of 13 to 30 days. The average pretreatment omall lymphocyte count wae $2300 / \mathrm{mon}^{3}$ whtch dropped to a level of $760 / \mathrm{man}^{3}$ at the cime of ekin grafting and was $740 / \mathrm{mon}^{3}$ at the time of graft rejection. Skin homografts in this group survived from 12 to 20 days. F1g. 3 (10wer part) deplete the enimal (\$136) which recelved irzadiation to 347 blood volumes at tranelt doses of 215-770 rads. 
B. ECIB AND IMORAH (AZATHOPRINE): 4 (Table I) Imuran hae been used as an Immunosuppressive agent alone or in combination with other druge, particularly to prolong renal homotraneplant ourvival $(39,40)$. We plenned some experimants to determine if a combination of ECIB and small non-toxic dosege of Imaran would yleld better resulta than ECIB alone. Three antmals recalved 1 to $1.5 \mathrm{mgm} / \mathrm{kg}$ body welght of Imuran I.V./day after an Intelel dose of twice this amount. There was no eigniflcant change in the level of lymphocytes during adminietration of Imuran. No prolongetion of skin homogreft survival was observad in any of these antmals, but the one animal on $1.5 \mathrm{mgm} / \mathrm{kg}$ of Imaran developed granulocytopenla, the granulocytes dropping from pretreatment level of $2800 / \mathrm{mm}^{3}$ to $400 / \mathrm{mm}^{3}$ by the $\mathrm{n} 1 \mathrm{nth}$ day. In all subsequent experimente a dose of $1 \mathrm{mgm} / \mathrm{kg} I . V$. dally wae employed.

Two animals recelved repetitive pregraft BCIB and postgraft Imuran. The trane1t doses were 750 and $2000 \mathrm{rads}$, and 106 and 49 blood volumes were 1rradiated. The duration of BCIB wes 70 and 49 hours over 8 and 5 days respectively. The average lymphocyte level prior to cormencement of $\mathrm{ECIB}$ was $3450 / \mathrm{mm}^{3}$, which dropped to $500 / \mathrm{mm}^{3}$ at the end of BCIB. Skin grafts were applied, Imaran started, and BCIB dlecontinued. Homografts survived for 16 and 15 daye respectbely. At the time of rejection the average lymphocyte level wae $1300 / \mathrm{mm}^{3}$.

In the next experiment, sx animals recelved pre- and post-graft repetitive ECIB and Imuran. The tranelt dose ranged from 500 to 800 rads, and number of blood volumes irrediated verled from 67 to 132 . The 
duration of ECIB was from 54 to 78 hours epread over periods of 7 to 17 days. Imuran was continued, however, unt1l the the of skin greft rejection in each animal. The average preexperimental level of amall lymphocytes of $3050 / \mathrm{mm}^{3}$ dropped to $500 / \mathrm{mm}^{3}$ at the the of skin grafting and rose to a level of $750 / \mathrm{mm}^{3}$ by the time of skin graft rejection. Skin homografta survived from 12 to 29 days.

C. TEORACIC DUCT LMMPH TREATMENT: (Table II) Calves \#165 and \#185 (PIg. 4) had centrifugation and return of cell-free lymph for 10 and 24 days respectively. The cumalative output of lymphocytes during these pertods was $9.3 \times 10^{11}$ and $14.1 \times 10^{11}$ respectively. Sk1n homografte vere applied at the end of treatment perlods and survived for 10 and 18 deys respectively. Pretreatmert levels of omall lymphocytes in the blood fell from $3400 / \mathrm{mm}^{3}$ and $3000 / \mathrm{mm}^{3}$ to $1800 / \mathrm{mm}^{3}$ and $1200 / \mathrm{amm}^{3}$ at the end of treatment pertod and rose to $3300 / \mathrm{mm}^{3}$ and $2100 / \mathrm{mm}^{3}$ by the time of graft rejection. Ca1f $\$ 186$ (F1g. 4), the tw1a of \#185, had ECIL for 22 days, and the cumulative output of lymphocytes that recelved irredietion was $13.8 \times 10^{11}$. Skin homografts were applied at the end of this trentment and survived for 22 days. The pretreatment level of amall lymphocytes fell from $3400 / \mathrm{mm}^{3}$ to $1100 / \mathrm{mm}^{3}$ and returned to $2100 / \mathrm{mm}^{3}$ by the time of graft rejection.

Calf |151 had cell-free lymph returned for 8 days, return of untreated lymph fur two lays and ECIL for 4 days. During the first 8 days $8.2 \times 10^{11}$ cells were removed by centrifugation. The number of amsil lymphocytes in the 
peripheral blood dropped from $5000 / \mathrm{mm}^{3}$ to $1900 / \mathrm{mm}^{3}$. A further drop to $800 / \mathrm{man}^{3}$ occurred durlng BCIL. Sk1n homografte, wich were applied at the and of treatment, survived for 40 days. The amall lymphocyte count in the blood at the the of graft rejectlon wa $1400 / \mathrm{mm}^{3}$. The untreated twin of thls antmal recalved ekln homografts from the and donor. Thene grefte ware rejected at 10 days.

In order to find an explanetion of our fallure to achleve long term survival of okla honografte with chronle trentment of thoracle duct $1 \mathrm{ymph}$, 1t was dectded to etudy the behavior of anterlor and postertor homografte. The anterior grafte, grafted onto the withere, are not usually in the dralange bed of the thoracle duct, but the posterlor homografte are completely withla 1te dralnage bed. Unrelated donors were uned for enterlor and posterlor homografte. Calvas $\$ 200$ (FIg. 5) and 202 had ECI for 34 and 68 daye. During this period the cumlative output of 1 gmphocytee vas $33.5 \times 10^{11}$ and $28.0 \times 10^{11}$ reapectively. Anterior and postarlor skin howogrefte vere applied 7 day after ECIL eterted. In calf 200 am 11 lyuphocytes in blood had:dropped from a pretrentmant level of $3000 / \mathrm{mm}^{3}$ to $500 / \mathrm{mm}^{3}$ at the time of grafting. Anterlor grafts were rejeeted is 22 days wh1le the BCIL was ot111 In progrees. Posterlor grafte aurvived the duration of BCIL. Bofection as evidenced by edem of the homograft comenced 2 days following fuccontinuation of ECIL and proceeded alowly to completion, the aurvival time of postertor grafts belng 39 days. In celf 202 , and 11 lymphoeytee in blood had dropped from a pretreatment $10 v e 1$ of $2400 / \mathrm{mm}^{3}$ to $600 / \mathrm{mm}^{3}$ at the time of grafting. Anterior grafts were rejected on day 27 wh1le ECIL was ot111 in prograsa. The animal died suddenly on the 68 th day of BCIl due to septicemis. At this time pooterior howografte were st111 in good cond1210n, 1.e., 61 daye after grafeing. Calf 1203 , the twin of 1202 , acted es an untrented comparison. 
Anterlor and posterlor grafte were re jeeted at 10 dage.

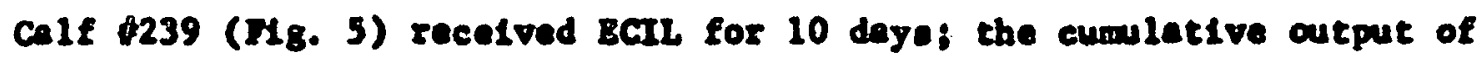
Iyuphocytes we $6.5 \times 10^{11}$. Small lywphocyted in the blood dropped from a pretreatment level of $2200 / \mathrm{mm}^{3}$ to $800 / \mathrm{man}^{3}$. At the termination of BCIL anterlor and poeterlor houografte vere applied, whleh aurvived for 18 daye.

Calf 206 (P1g. 5) recetved BCI for 25 dags, and the cumslettve output

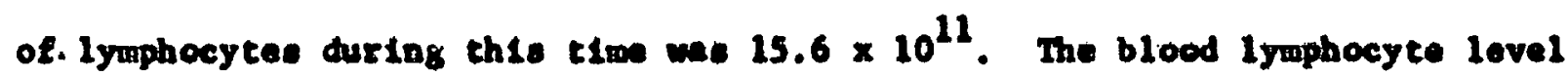
dxopped from $3500 / \mathrm{man}^{3}$ to $300 / \mathrm{mm}^{3}$ by the 15 th dag of RCLL but rose up to $900 / \mathrm{mm}^{3}$ by the last day of BCIL. Antertor and postertor skin homografte were applied juat before the commencempat of BCIL. Anterior grafte wore rejected on day 13 wh1le BCIL we ot1ll in progrese. Poaterlor grafts eurvived the duration of EGL. Evidence of graft rejection was noticed vithin 24 hours of diecontinuation of BCIL. Total survival tim for posterlor grafte was 28 days. In order to exclude any offect of 1rzadlation on cell-free lyoph itaelf, a thorectc duct-rumen fletula we esteblished in celf 4209 . Lymph was pumped from thoracic duct to rumen for 26 dage. During this pertod, $22 \times 10^{11}$ lymphocytes eatered the rumen frow the thosecld duct and were preaumbly dentroyed. Blogd lymphocytes dropped frow a pretreatment $10 v e 1$ of $3200 / \min ^{3}$ to $700 / \mathrm{mm}^{3}$. Antertor and postertor okin honografte were appliod 7 daye after thoractc duct-rumen fletula was establiohed. Four days later the thoracic duct canmule was partially clamped to tuduce the lyaph output from 3 litero/ hour to 1.5 1ftera/bour, In order to prevent bypoprotenemla and diarrohea (41). Anterlor and posterior grefte ourvived for 14 and 18 daye reopactively. Drscussion:

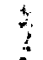

BCIB modified the normally ceute and violent homograft refection procese to a mild and olow one in all the cesen at all tranolt doces. There wae, 
however, no elgniflcant lacrease In okin homograft aurvival with pregraft ECIB alone et tranalt doses varying from 15 to 1000 rads. Somewhat beter reaults were obtalned in anlwale which recelved repetitive pre- and post-graft ECIB et transit dose renge of 200-800 rads. In ore andmal the okin graft survivel time was prolonged to 20 daye from the normal of 8-10 dage. Comblnation of ECIB and Imuran reaulted in a very olight Improvoment in reaulto. The wadiol skln graft curvival tim wa 29 daye in thie group. Fallure of Imaran to contribute olgatflenty to reoulte weo not ourprialng olnce we used rather omll nop-toxtc doses. In addition, although Imuran heo

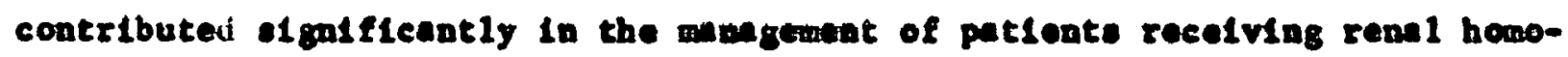
transplants (42) it was found to be of 11tele value in prolonglng the eurvivel of akln homografte in doge (43). Ine fallure of rCI. to markedly prolong the okin horogreft curvivil, though dieappolnt1ag, can be explelned by the fact that ECIB k111s only a fract 10 of the recycilag imanologleally compotent and lununologleally cetivated and1 lymphocyter by ohuntiag only a portion of the blood through the lrradlator (B.8. 7). Bven a doubling of the normal okin greft rejection tim, however, cannot be completely 1 gnored as bettor reaults my be poselble in other organe, ach as the kldney, in which rejection is 1 ees violent. Preliminary studies to ovaluete the role of BCIB In comblantion with irmunocuppresalve therapy to prolong the lifo of reanl homotreneplant in pationte are in progrese in collaboration with Dr. J. P. Merrill' gxoup of Peeer Dent Brighum Houpleal, Boston (44). BCIB any alco condition clopely related rectplent-donor patre elthot alete or in combination with BCIL to postpone ehdingtitution of cytotoxic druge with all thelr undealrable elde affecte.

IIORACIC DuCT LYYP: We had the following three questione in atind when trantmont of thoracic duet lyuph we contcropleted in order to prolong 
skin homograft ourvival:

1) Do the products of cell death or cell bound antibodies that are returned to the animal as a result of ECIB have a deleterious effect on homiograft survival?

2) Io there any difference between blood and thoracle duct lymphocytes?

3) W111 there be a beter wutwal of those skin grafte which are pleced on those parts of the body that are drained solely by the thorecic duct?

To answer the f1ret question, twin pair \$185 and $\$ 186$ was atudied (F1g. 4). Calf 185 had centrigugation and return of cell-free lymph for 24 days. Calf 186 had ECIL for 22 daye with return of all 1rrediated cella and any products of cell death to the andmal. There was, however, very close approximetion in the cumilative output of lymphooytes, blood 1 ymphopente and skin graft ourvival time in these to calves. This experiment did not show any deleterloun effects of producte of cell desth on honograft survival. The enower to the second question is et111 not clear. The lowest level. of lymphocytes were obtainad with prolonged ECIB, yet the longent anterior homograft survival follosed BCIL. The observed differences between mean ourvival were not etatistically olgaficant, however. We are not inclined to belleve thet there are fundamental differences between the blood and thoracte duct lymphocyres.

It 18 clear from Figure 7 that whatever the mode of eensitization, centrel at the atte of the graft or in the reglonal lymph node due to the arrival of the graft antigen via lymph veseale (45), the Immunologically activated Bmsll lymphocyte (25) can get at the posterlorly placed graft only by reaching the blood stream vis the thoracte duct. If one prevented these 
activated celle from resching the blood strenm by cannulating the thoracic duct and removing or deatroylng these cells, then the posterlorly placed graft would be expected to survive for as $100 \mathrm{~g}$ as these activated colle were prevented from recinhing the graft. Ints was the case in calves $\$ 200$ and \#202. These calvas recelved okin grafts 7 days after BCIL was started. Anterior grafts on the withers on the right olde vere rejected during BCIL. Posterior grafte in the drainage bed of thoracle duct ware not rejected durfag BCIl. Further Indirect support for thle hypothesis wa provided by the next set of experiments. If our reaponing in regard to the different behavior of antarior and posterior sk1n grafts 18 correct, then pregraft lymphocyte depletion of the antmal th not required for prolongation of gurvival of posterlor grafts. By the same token, if an entmal is depleted before grefting but treatment is discontinued after grsfting, the survival of anterior and posterfor grafte should not differ. Both of these expactations ware borne out by experimente desertbed below. Calf pob recelved anterlor and posterior skin homografte fust prlor to commencement of RCIL. As expected, the anterlor grafts were rejected durtng ECIL while posterfor grafte were rejected three daye after ECIL wae discontinued. Calf 239 recelved ECIL for 10 daye. One day after termination of BCIL, enterlor and posterlor grafts were applied, all surviving for 18 days. The next expertment was designed to rule out any Influence of lrradiation on cell-free lymph itaelf in prolonglng the homgraft survival. A thoracle duct-rumen flstula was established In calf \$209. Prevloun vork (46) hed phown that in such preparations the degree of blood lymphopenla produced 1s comparable to that produced by BCIL or by centrifugation and return of cell-free lyoph. Th1s lymphopenla is preoumbly due to the dentruction of thoracic duct lywphocytes in the rumen. 
The, only problem in these anlmalo to progressive hypoprotenemis followed by severe dierrhoes and death after 2-3 weeks. The 1 deel experiment would be to remove the celle machanically but we are not aware of the exlotence of any centrifuge that u111 work contimously for weake and remove $100 \%$ of cella from 50-80 11tree of lymph/day. Even a mall umber of escaplag activated 1ymphocytes may be oufficlent to destroy the graft. Anterlor and posterlor skin homografte were applied soven day after the thoracic duct-rumen fletula wes established, and these grafte arvived for 14 and 18 daye respectively. The degree of blood lymphopenla end cumlative cutput of lymphocytes wae cómparable to antmals treaced with BCIL or contrifugation (PIg. 4). Rejection of posterior grafte occurred while the thoracid duct-rumen fietula was atill fünctlonlng. We belleve that thle was due to partiel dellberate obetruction of thoracle duct as deseribed above and absequent opening up of collaterale, or lymphatico-venous channels. A fow activated lyuphocytes might have reached the blood atrean and ettacked these grafte.

Under the coaditions of our experimente, there to no defintte evidence that the reglonal lymph node reaponse to first set posterlor ikin homografts epreade to dietant nodes the effector limb of the rejection procese is interrupted at the thorecic duct. The realts oupport the hypotheale that viable ectivated lymphocytes from the seneltised reglonal lywph nodes are essential for the firet set skin homograft rejection. It is a posibility that these ectivated cells any require further proceselng during their transit through ther body tiswee before these celle can react agalngt the graft. In view of the rapld onset of posterlor homograft rejection after discontinuation of BCIL this seams attikely. The procodure makes posetble furthor atudies on the banc phepononologg of honograft refaction. One 
could further Investigate effector and effector limbe of the rejection procese ut1listng reglonal BCIB and BCIL. Studles ut1lising these techntques are In progrese to inveetignte the role, If any, of a humoral antibody in the flrst set skin homograft rejection. SUIRARY:

Effects of extracorporeal Irradiation of the blood (BCIB) upon skin homograft ourvival in calves have been described. In all gCIB-treated calves, the norwally acute and blolent aklo hougraft rejection process was modifled to a mild and slow one. Frolongetion of akln hougraft aurvivial ranged fron 1-11 daye. Comblnation of BCIB and Inuran givon In omall non-toxle doses improved recults to a allght degree. Prolongation of okfin homograft survival in thls group renged froal 3 to 20 daye. The poselble rensons for these reaulte are discussed.

Experlments lovolving thorecle duct lymph dralnage were conducted in nine calves. The procedures for handling the lymiph included 1) extrecorporeal Irradlation of lymph (ECIL), 2) contrifugation of lymph and return of cellfree lymph to the animal, 3) pumping of untreated lymph to the rumen in one animal with a thoracic duct-ruman flatula. Only one animal, which was treated by centrifugation and roturn of cell-free lyoph for 10 days, falled to show any prolongation of ekla graft eurvival. Proloagation of eurvival time of anterlorly placed grefta ranged from 4-31 daye in 8 calves. Posterlorly placed grafte aurvived the duration of treatmant wich ranged from 25-68 daye in three animale. Implications of the results with perticuler reference to the different behavior of ancerior and pooterlor grafte ere discuseed. 


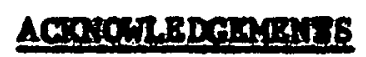

We wheh to exprese aur thanks to Hr. C. R. 81pe, Mr. B. R. Adamik, Mr. T. Waldon, and Mr. F. Corbla for axcellont technienl asuletunee during all the phesen of thle rescareh work. 


\section{Fo0020018 8}

1 Avallable fran Ixtracorporeal and Medical Specialtios Co., Inc., Medford, How Jersey.

2 Vartable Spaed Per1statt1c Purup, Model 505-1200, Barvard Appl1ance Company, Dover, Maseschusetts.

Internaticanl Bqulpment Company, 302 Avenue, Heedbam Hel ghte, Menchusetts, 02194 .

4 Rindly cupplied by Dr. Donsld s. Senrle, Madical Director, Burroughe Wellcome and Co., (USA) Ine., I Scaradale Road, Tuckahoe, R.Y. 10707. 


\section{BREEREICES}

1. Scothorne, R.J. studies on renponse of reglonal lymph nodes to akin homografte. Ann. N.Y. Acad. Sc1., 64: 1028-1039, 1957.

2. Blnet, L.J., and G. Methé, Optical and electron microscope atudies of Immunologically competent cello in graft reject1on. Mature, London, 193: $992-993,1962$.

3. Burwell, R.G., Studies of the primery and secondery lmwune responses of the lymph nodes draining homogrefts of fresh cancellous bone (with particular reference to mechaniom of lyroph node reactivity). Ann. N.Y. Aced. Sc1. 99: 821-860, 1962.

4. Rymazewska, T., R. Wloderak1, L. Tomersewsk1, M. Zalesk1 and W. Plonka, Studies on lymph from the efferent vessel of reglomil node after heterotransplantation. Transplantation 3: 114-118, 1965.

5. Medawax, P.B., The behavior end fate of skin autografts and akin homogrefts in rabbits (report to War Wounds Conmittee of Medica; Research Counc11). J. Anat. London, 28: 176-199, 1944.

6. Wakeman, B. H., The pettern of rejection in ret okin homografte and ite relation to vescular network. Iab. Invest. 12; 46-57, 1963.

7. WLener, J., D. SpIro, and P.S. Buseel, An electron mlcroscople study of the hómograft react1on. Amer. J. Path., 44: 319-345, 1964.

8. Elchweld, E.J., and E.C. Lustgreaf, Histology of bex opeciflc graft rejection. J. Nat. Cancer Inst., 26: 1395-1401, 1961.

9. Porter, K.A., H. H. Joseph, J.M. Readall, C. Stollnok1, R.J. Hoehn, and R.Y. Calne, The role of lyophocytes in rejection of cantne renal homotranoplante. Lab. Invest. 13: 1080-1098, 1964. 
References, continued

10. BLIIIngham, R.E., W.K. SIIvers, and D.B. WLlson, Further studles on edoptive transfer of sensitivity to okin homografts. J. Exp. Med. 118: 397-420, 1963.

11. Gowang, J.L., D.D. McGregor, D.M. Cowan, C.B. Pord, Inttiation of Imaune responses by sma11 1ymphocytes. Neture, London, $1968651-655,1962$.

12. MIIlex, J.F.A.Z., Effect of neonetal thymectomy on Immunologtcel responsiveness of mouse. Proc. roy. Soc. S.B., 156: 415-428, 1962.

13. McGregor, D.D., and J. I. Gowans, Survival of homografte of skln In rate depleted of lymphocytes by chronle drainage from thoracle duct. Iancet 1 : 629-632, 1964.

14. Woodruff, M.F.A., and N. A. Anderson, The effect of lymphocyte depletlon by thoractc duct flstula and adminiatration of antlymphocyte serum on the survival of skin homografts in rats. Neture, Iondon, 200: 702, 1963.

15. Na jarian, J.S., and J.D. Feldman, Observations on paselve transfer of transplantation 1mmulty and delayed hypersensitivity with lymphoid cells In m1111pore chambers, Traneplantation, 1: 495-501, 1963.

16. Stetson, C.A., Role of humoral antibody in honograft rejection, Advanc. Immol., 3: 97-103, 1963.

17. Stlverstelu, A.M., and M.L. Krener, The role of clrculating antibody in the rejection of homografts. Traneplantat1on, 3: 535-541, 1965.

18. Dempster, W.J., B. Lennox, and J.W. Bang, Prolongation of survival of skin homotransplants in the rabblt by 1rradiation of the host, Brit. J. Exp. Pathol., 31: 670-679, 1950.

19. Calne, R.Y., G.P.J. Alexandre, and J.B. Murray, Study of effects of druga In prolonglng survival of homologous renal traneplants in doge. Ann. N.ł. Acad. Sc1., 99: 743-761, 1962.

20. Schwartz, R., and $w$. Damohhek, Bffect of 6-Marcaptopurino on holnograft renctions. J. Cl1n. Invest., 39: 952-958, 1960. 


\section{References, continued}

21. TIlak, S.P., and J.M. Howard, Salectlve lrxadlation of lymph nodes as a mens of conditioning for homotransplantation. Surg. Forum, XV, 160-161, 1964.

22. Cronk1te, E.P., A.D. Chanan, and Hp. Schnappauf, Extracorporeal Irrad1ation of blood and lymph In animale: Its effects on homografts and on lymphoma. New Eng. J. Med., 272:456-461, 1965.

23. Tunner, W.S., P. P. Carbone, W.R. Blaylock, and G.L. Irvine, III, Effect of thoractc duct lymph drainage on the lmmune response in man. Surgery, Gynecology and Obstetrics, 121: 334-338, 1965.

24. Wright, E.S., and I.W. McFhee, the effect of lymphocyte depletion and Aypogammaglobulinemla on the ourvival of skin homografta. Surg. Gynae. Obstetr1ce, 121; 1052-1058, 1965.

25. Gowans, J.L., and E. J. Knight, the route of reclrculation of lymphocytes in the rat. Proc. roy. Soc. 8. B., 159: 257-282, 1964.

26. Duculng, J., L. Bugnard, and 0. Miletsky, Act10n des rayoas x Sur le sang circulant extér1oríse. Acta, Union Internat. Centre Cancer 4: 825-830, 1939.

27. Cronkite, B.P., C.R. Jancen, G.C. Mather, M.O. Mlelson, B.A. Usentk, E.R. Ademik, and C.R. Slpe, Studies on lymphocytes I: Lymphopenta produced by $\therefore$ prolonged extracorporenl lrreldiation of elrculating blood. Blood, 20:203, 1962.

28. Slatkin, D.N., C.R. Jansen, E.P. Cronktte, and J.S. Robertson, Extracorporeal Irradiation of blood: Calculation of radiation dose, Rad. Res., 19:409-418, 1963.

29. Cronkite, E.P., C.R. Jansen, H. Cottier, R.R. Ra1, and C. R. Stpe, Lymphocyte production measured by extrecorporeal irradiation, cannulation and labeling techniques. Amn. N.Y. Acad. Sc1. 113:566-577, 1964 .

30. Cottler, H., E.P. Cronklte, C.R. Jansen, R. R. Ra1, and S. Singer, Studies on lymphocytes III. Effects of extrecorporeal Irradiation of blood upon lymplioietlcular organe in the cale. B100d, 24: 241-253, 1964. 
31. Ruhl, O.A., W. Rlpperger, D.W. Hussegh, and E.P. Cronkite. Cobalt-60 1rradiator for extracorporeal blood irradiation. Nucleonics 22: 79-83, 1964.

32. Sipe, C.R., A.D. Chanana, Bp. Schnappauf, D. D. Joel, and B.P. Cronk1te, The influence of varying dose and repetitive short sesolons of extracorporeal 1rradiation of the blood upon the production of lymphoponia. Rad. Res.. 25: $684-694,1963$.

33. Schinappauf, Hp., D.D. Joel, A.D. Chabana, R. D1Giacomo, and E.P. Cronklte, The influence of in vitro irradiation on red cell survival after auto- and homotransfusion of cells labeled with Iron-59 and Chromlum-51, Rad. Res. 25: $646-654,1965$.

34. Chanana, A.D., and E.P. Cronkite, Sempermanent extracorporeal erteriovenous and thoracle dinct shunts in bovines. To be published in Amer. J. Vet. Res.

35. Gowans, J.L., The role of 1ymphocytes in the destruction of homografts, Br1t. Med. Bu11., 21: 106-110, 1965.

36. Chanena, A.D., G. Brecher, and E.P. Cronk1te, Histologic observations on okin homograft rejection in calves. Submitted to Tranoplantation.

37. Anderson, D., R.E. B1llingham, G.H. Lambkin, and P.B. Medawar, The use of skin grafting to distingulsh between monozygotic and dizygotic twins in cattle, Heredity, 5: 379-395, 1952.

38. Chanana, A.D., G. Brecher, E.P. Cronk1te, D.D. Joel, and Hp. Schneppauf, The influence of extracorporeal irradiation of blood and lymph upon skin homograft rejection. In press, Rad. Res.

39. Calne, R.Y., Inhibltion of the refection of renal hoinografts in dogs by purine analogs, Transplantation Bul1., 28: 65-81, 1961.

40. Hume, D.M., J.H. Magee, H.M. Kauffman, Jr., M.S. Rittenbury and G.A. Prout, Renal homotransplantation in men in modified reciplents, Ann. Surg., 158: 608-641, 1963. 
References, continued

41. Joe1, D.D., A.D. Chanana, and E.P. Cronkite, Unpublished observations, 1965.

42. Murray, J.E., Human Kidney Traneplant Conference, (Sept, 26-27, 1963) Trensplantation, 2: $147-155,1964$.

43. Hechtman, H.B., D.A.Blusenstock, E.D. Thomas, and J.W. Perrebee, Prolongation of canine skin homografte by antimetabol1teof Surg. Forum, 13: 55-57, 1962.

44. Merr111, J.P., E.P. Cronk1te, L.M. Schiffer, and C.B. Carpenter, Extracorporeal Irradiation as an ad junct to Imanunosuppreselve therapy. Submitted to N.Y. Acad. Sc1., Traneplentation Conference 1966.

45. Lambert, P.B., H.A. Frank, S. Bellman, and D. Farnoworth, The role of lymph trunks in the response to allogenelc skin transplants. Transplantation 3: $62-73,1965$.

46. Chanana, A.D., E. P. Cronk1te, and D. D. Joel, Unpublthhed observations, 1965. 


\section{PICURE LEGENDS}

Figure 1. Show arrangement for ECIB.
$A \rightarrow$ erterial and of shunt connected to irradiation coll.
$v \rightarrow$ venous end of shunt connected to irradietion coll.
$I \rightarrow$ Cobalt -60 irradiator.
$g \rightarrow$ Heparin Infusion pump.
$W \rightarrow$ Weter beth for pumplng water at $40^{\circ} \mathrm{C}$ around that portion of lreadiation coll which to outalde the irradiarioa chamber.
$\eta \rightarrow$ thermometer.

F1gure 2. Shows arrangement for centrifugation of lyraph and return of

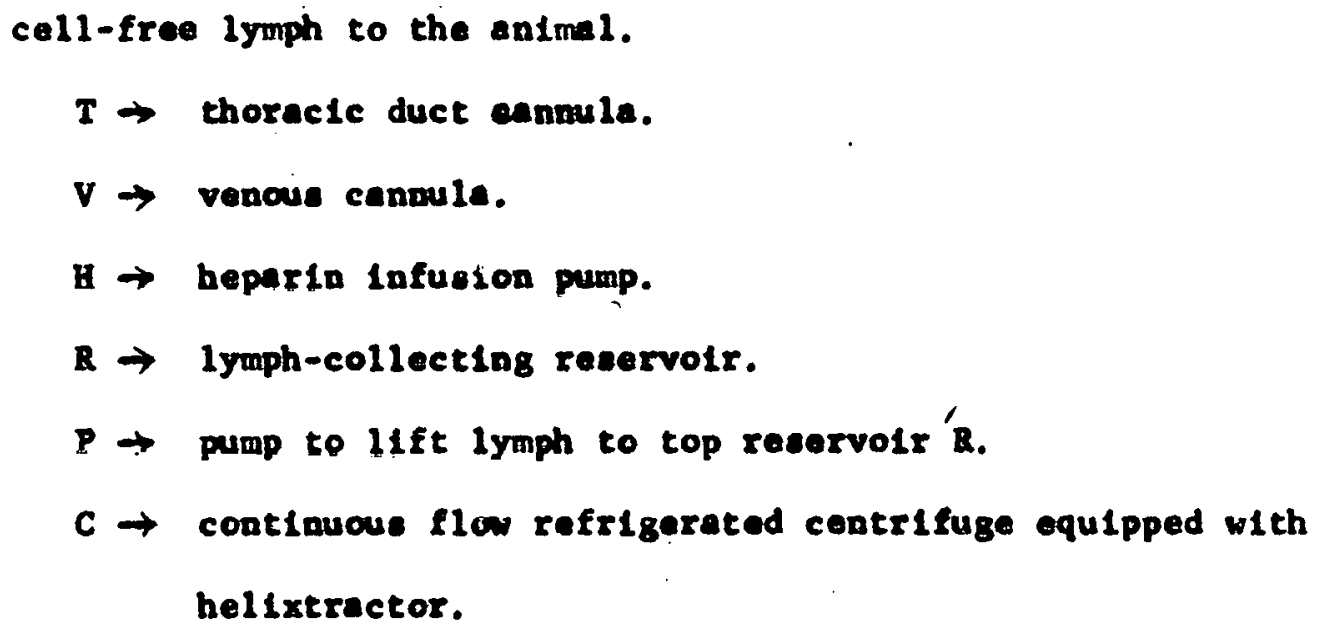

Flpure 3. Show influence of ECIB on number of lymphocytes in peripherel blood.

Top 24 hours continuous ECIB. Average of a1x calves. Mddle
(1113) Fregraft repet1tive ECIB. 


\section{Brure 3, contioned}

Bottom Pre- and post-graft repetitive BCIB.
$(136)$.

$$
\begin{aligned}
& G \rightarrow \text { Day of ekls homografting. } \\
& \mathrm{R} \rightarrow \text { Day of akln homogreft rejection. }
\end{aligned}
$$

Pleure 4. Stowe Influence of varlous treatmente of thoracic duct lymph on number of lymphocytes In puripheral blood and cumulative output of 1yuphocytes from thoracte duct.

$$
\begin{aligned}
& \text { Top (\$209) Thoracle duct - Buman E1etula. } \\
& \text { Midd1e (\$185) Bxtrecorporeal Irrediation of Lywph (BCIL). } \\
& \text { Botton (180) Centrifugation and return of cell-frea } \\
& \text { lyoph (C-L) to the animel. }
\end{aligned}
$$

T-D. C. $\rightarrow$ Thoracic duct cannulation.

T-D. R. $\rightarrow$ Thoracic duct-rumen f1stule.

$G \rightarrow \quad$ Day of skin homografting.

B- and R-A $\rightarrow$ Dey of rejection of anterlor akln grafte.

Q-P $\rightarrow$ Day of rejection of posterior skin grafts.

I1mire 5. Show Influence of BCIL on number of Iymphocyten in perlpheral blood.

Top $(206) \rightarrow$ Pre-BCLI antertor and posterdor okln grafting. MLdd• (1239) $\rightarrow$ Post-BCIL antertor and posterlor okin grafting. Botton $(\$ 200) \rightarrow$ Anterior and postertor okln grafting one week efter cemoncement of RCIL. Calf $\$ 200$ also recelved BCIB for $2-4$ houre a day for 9 daye to etudy the Influence of BCIB on output of ce11. Irem thoracie duct. 
Elare S, Contloued

T-D.C. $\rightarrow$ Thoracle duct canmilation.

C. $\rightarrow$ Day of okin howografting.

$R-A \rightarrow$ Day of refection of anterlor skin graft.

$R-P \rightarrow$ Day of rojection of posterlur okin graft.

Flgure 6. Showe the ajpearance of okla grafte in animel 206,24 days after grafting.

a. $\rightarrow$ Postorlor okln howografte. 4 healthy grafts are shown.

$A \rightarrow$ Postarlor okln autografte. 2 healthy grafts are shown.

Figure 7. Th1s diagranmatic sketch shows the poselb1e roles of Irmunologleally competent. amall lymphocytes and Immunologlcally activated amall lymphocyted in the posterior skin homogreft rejection. Ae an arterlo-venous shunt diverte only a portion of the blood etrean through the irredietor, ECIB can destroy oaly a portion of lunnologically competent and activeted axall lyaphocytes. Camoulation of thoraelc duct removes only a portion of Imanologlcally competent omil lymphocyted as reelrculetion from blood to other lymph channels remelns uninterrupted. Capmulation of thoracic duct removes all the aetivated unall lymphocyten in cese of posterlorly pleced homograft and thus prevente the destruction of homograft.

Th1s sketch also showe the posetble mechandems of senstitr sation:

1) Contral seneletention due to interection of Inownologically competent and1 lymphocyte and graft antigea.

2) Senoltization in the regloal lymph nodo by free or wecrophege boxe graft entigen. 


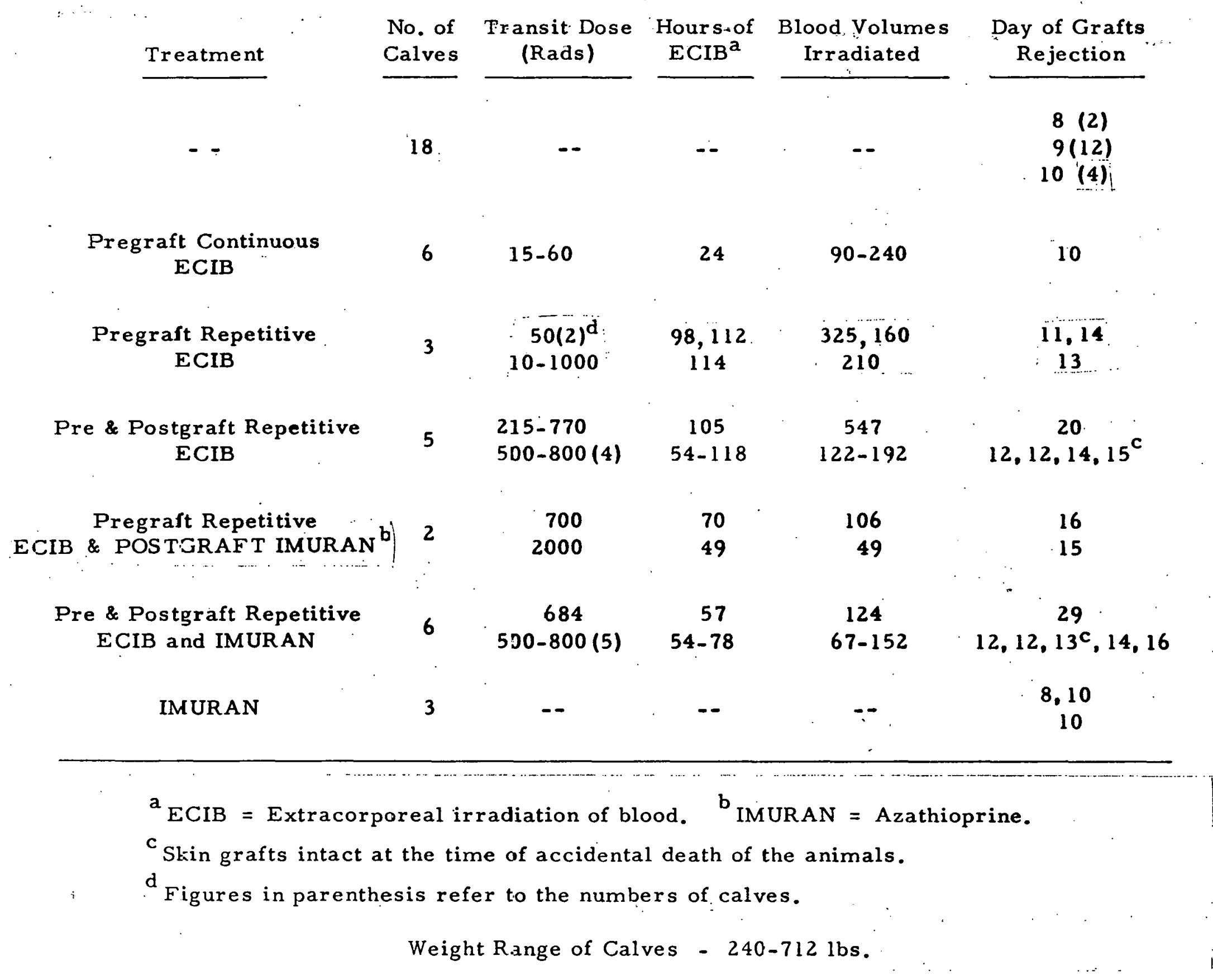




\section{THORACIC DUCT LYMPH VS SKIN HOMOGRAFT REJECTION IN CALVES}

\begin{tabular}{|c|c|c|c|c|c|c|c|c|}
\hline \multirow{2}{*}{$\begin{array}{l}\text { Calf } \\
\text { No. }\end{array}$} & \multirow{2}{*}{$\begin{array}{l}\text { Treatment } \\
\text { of Lymph }\end{array}$} & \multirow{2}{*}{$\begin{array}{c}\text { Days of } \\
\text { Treatment }\end{array}$} & \multicolumn{2}{|c|}{$\begin{array}{l}\text { Lymph Output } \\
\text { Per Minute } \\
\times 10^{8} \\
\end{array}$} & \multirow{2}{*}{$\begin{array}{l}\text { Cumulative } \\
\text { Lymph Output } \\
\times 10^{11} \\
\end{array}$} & \multirow{2}{*}{$\begin{array}{c}\text { Day } \\
\text { Grafted }\end{array}$} & \multicolumn{2}{|c|}{$\begin{array}{c}\text { Graft Rejection } \\
\text { Time (Days) }\end{array}$} \\
\hline & & & Min. & Max. & & & Anterior $^{a}$ & Posterior ${ }^{2}$ \\
\hline 151 & CENT. $^{b} \&$ ECIL $^{c}$ & $14^{\mathrm{e}}$ & 0.2 & 4.3 & 8.2 & 14 & 40 & -- \\
\hline 165 & CENT. & 10 & 0.25 & 2. & 9.3 & 10 & 10 & -- \\
\hline $185^{f}$ & CENT. & 24 & 0.24 & 1.04 & 14.1 & 24 & 18 & -- \\
\hline $186^{\mathrm{f}}$ & ECIL & 22 & 0.22 & 1.18 & 13.8 & 22 & 17 & -- \\
\hline 200 & ECIL & 34 & 0.28 & 2.05 & 33.5 & 7 & 22 & 39 \\
\hline 202 & ECIL & 68 & 0.14 & 1.4 & 28.0 & 7 & 27 & 61 \\
\hline 206 & ECIL & 25 & 0.13 & 2 & 15.6 & 1 & 13 & 28 \\
\hline 239 & ECIL & 10 & 0.3 & 2.3 & 6.5 & 10 & 18 & 18 \\
\hline 209 & $T D-R^{d}$ & 26 & 0.12 & 4.9 & 22 & 7 & 14 & 18 \\
\hline
\end{tabular}

${ }^{a}$ For details see text.

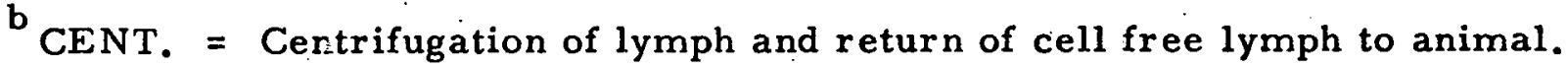

$C_{E C I L}=$ Extracorporeal irradiation of lymph (Transit Dose Range 450-5000 rads).

d $T D-R=$ Thoracic Duct - Rumen Fistula.

e CENT. from Day 1-8 ECIL from Day 10-14. Cumulative Output from Day 1-8 only.

f Twins with common donor.

$$
\text { All Animals - Holstein Weight Range 174-475 lbs. }
$$




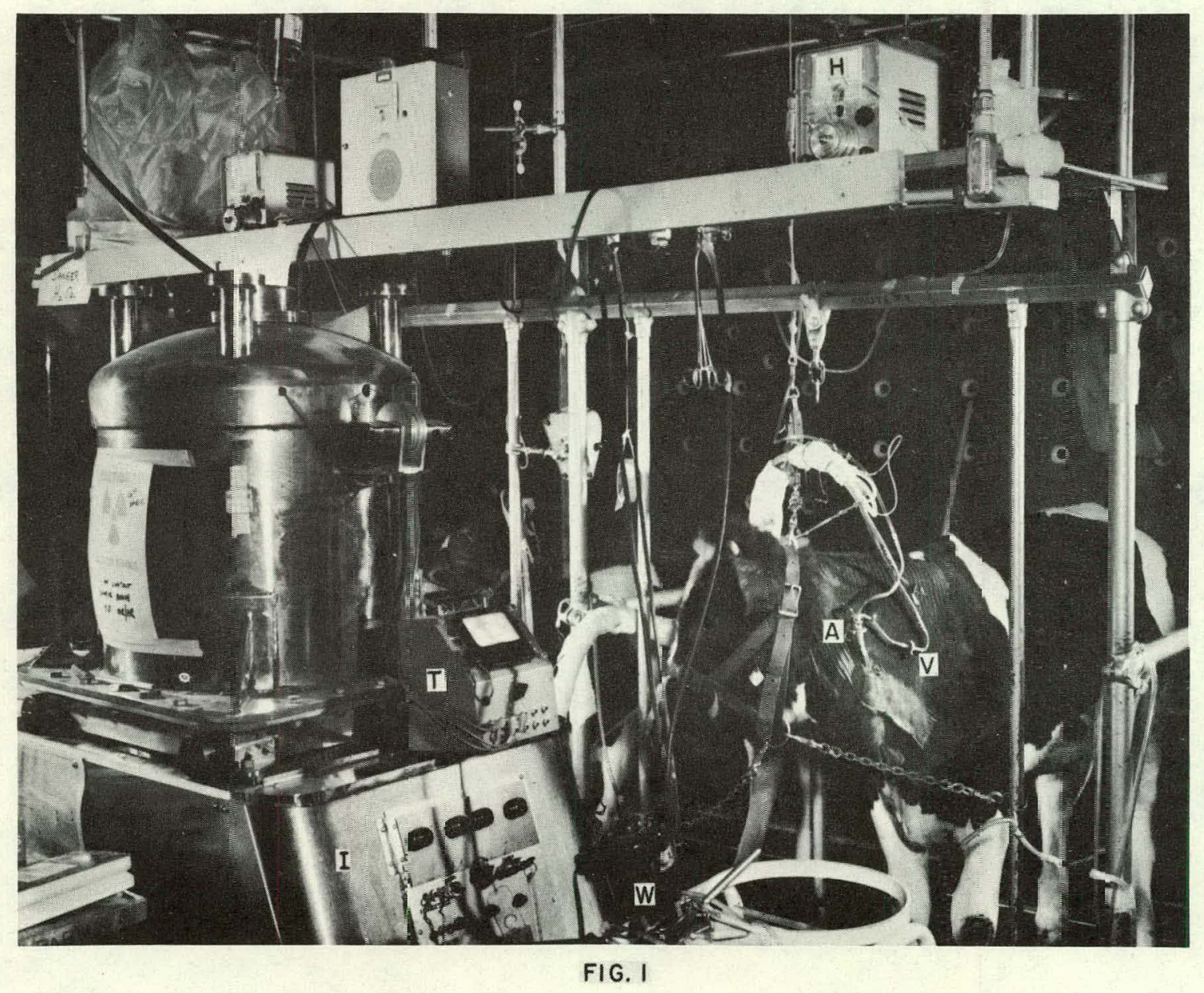




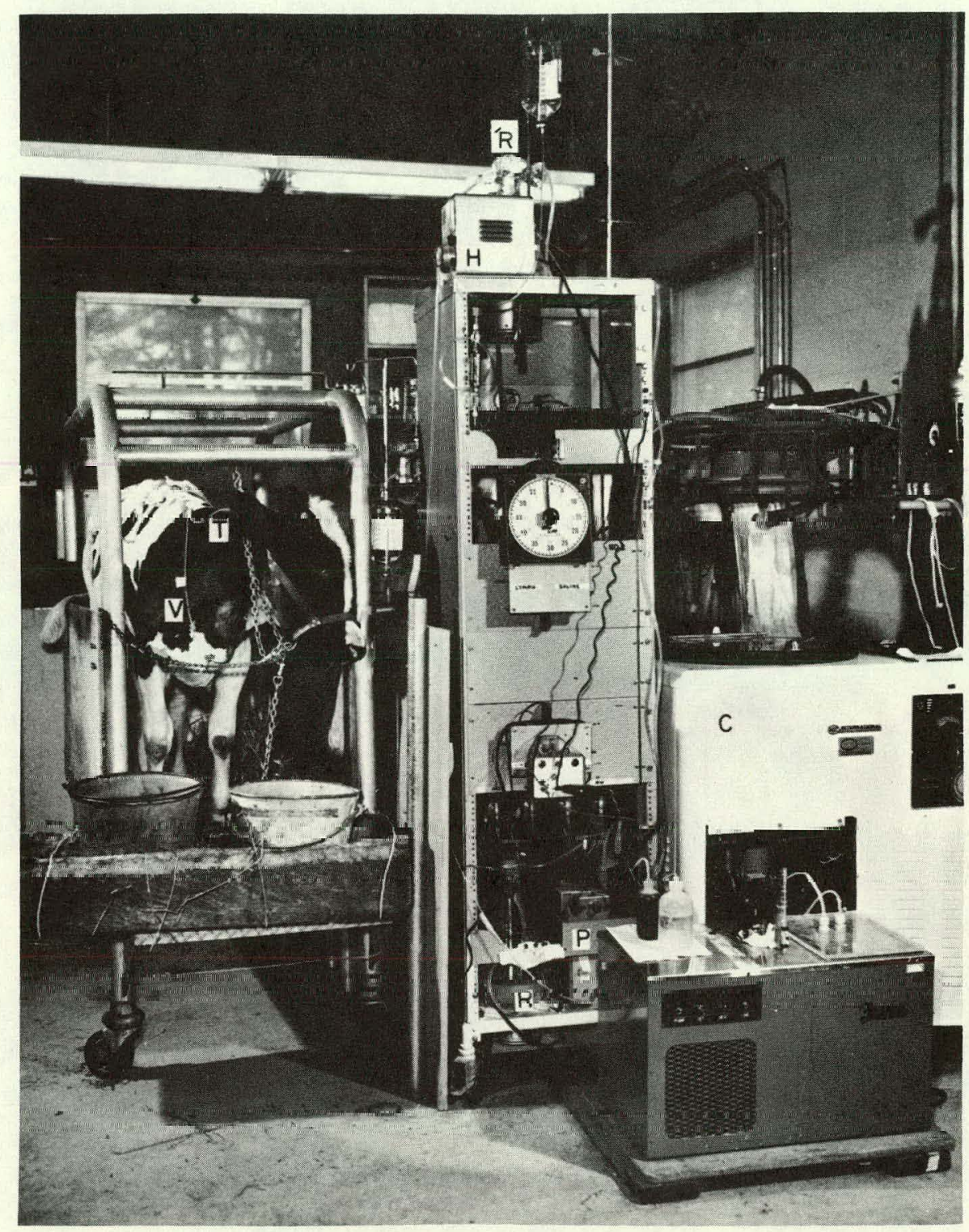

FIG. 2 


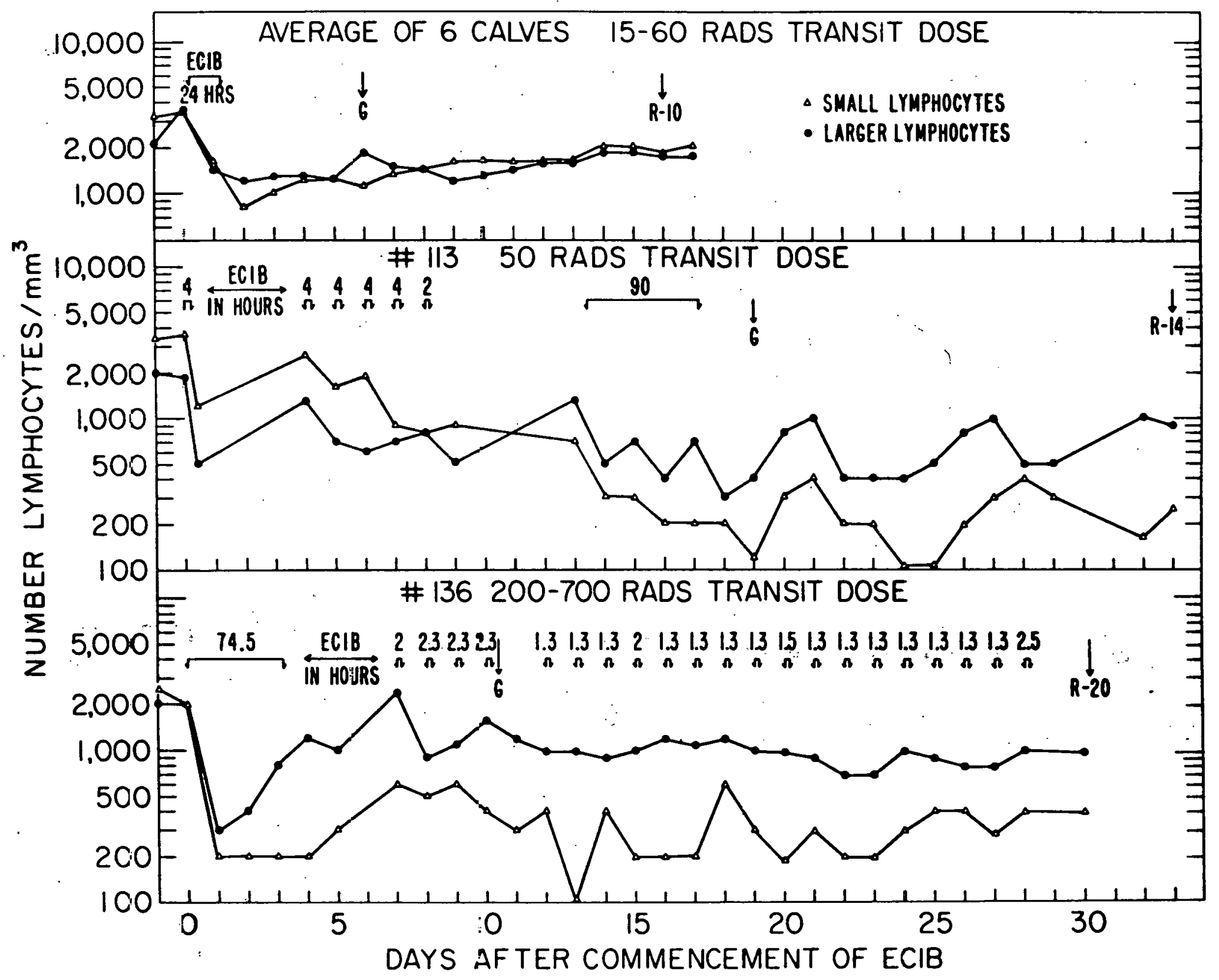

$F, \in]$ 


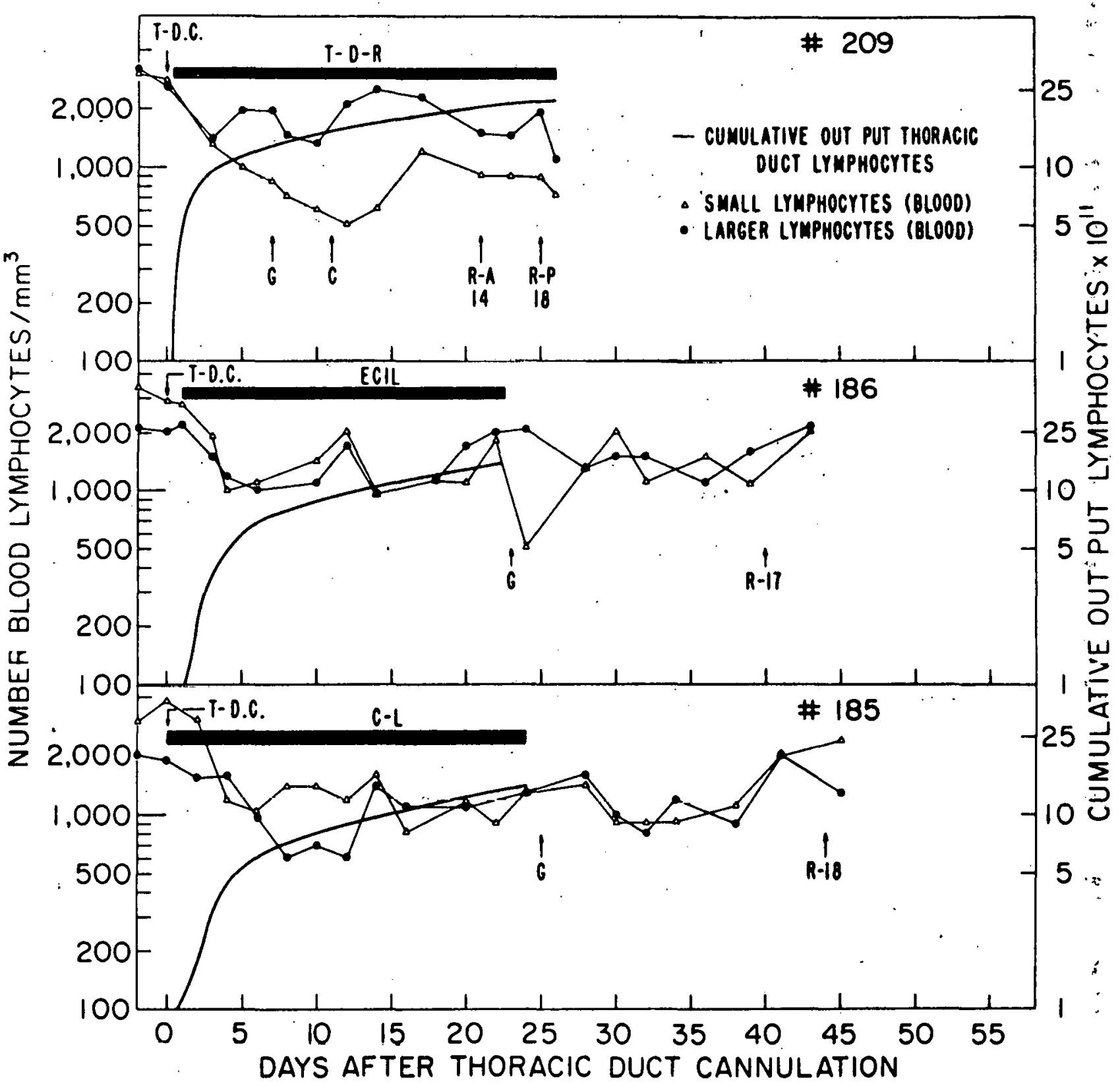

$i$
$i j$
4 


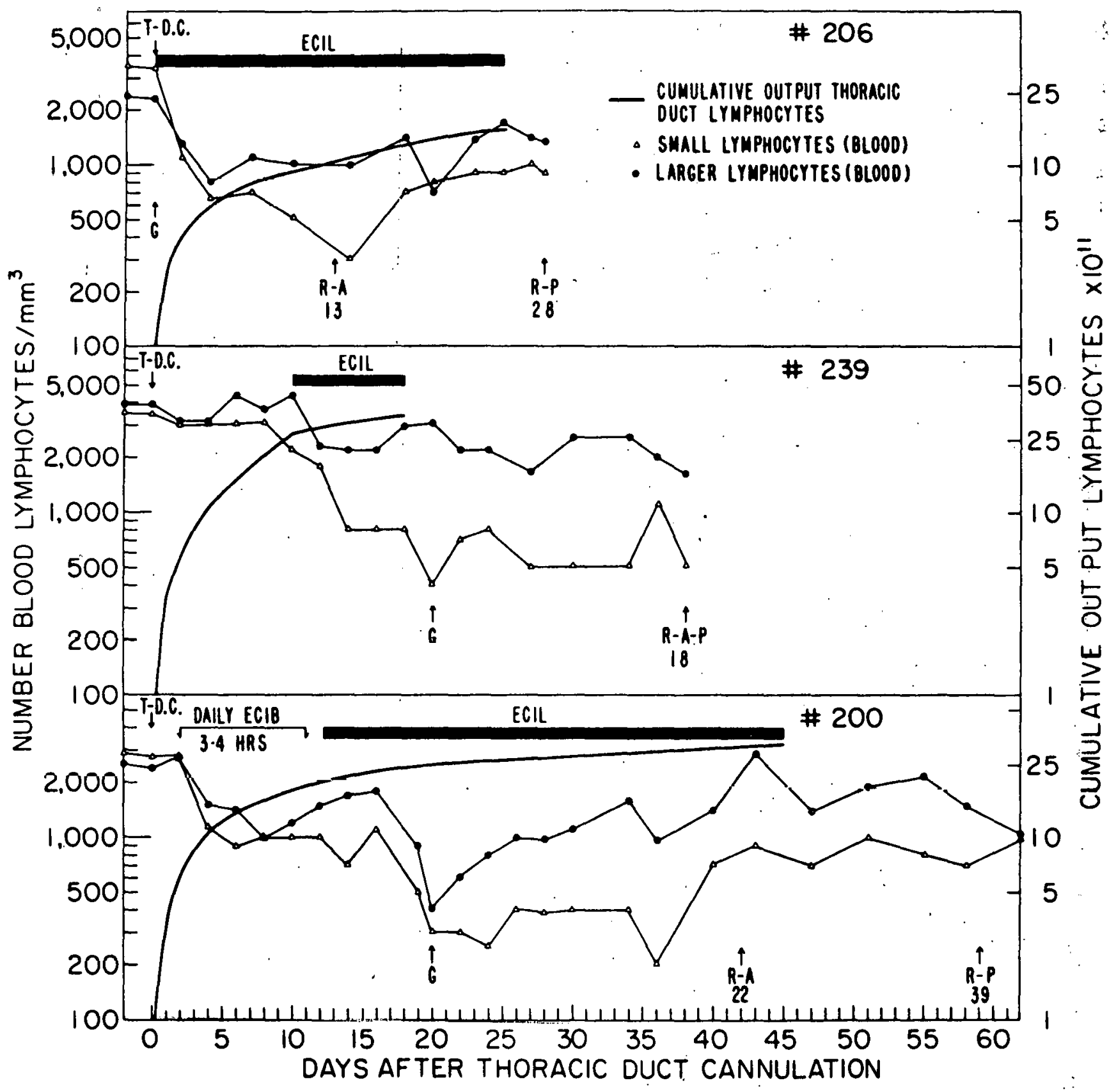

$$
\text { FIE }
$$




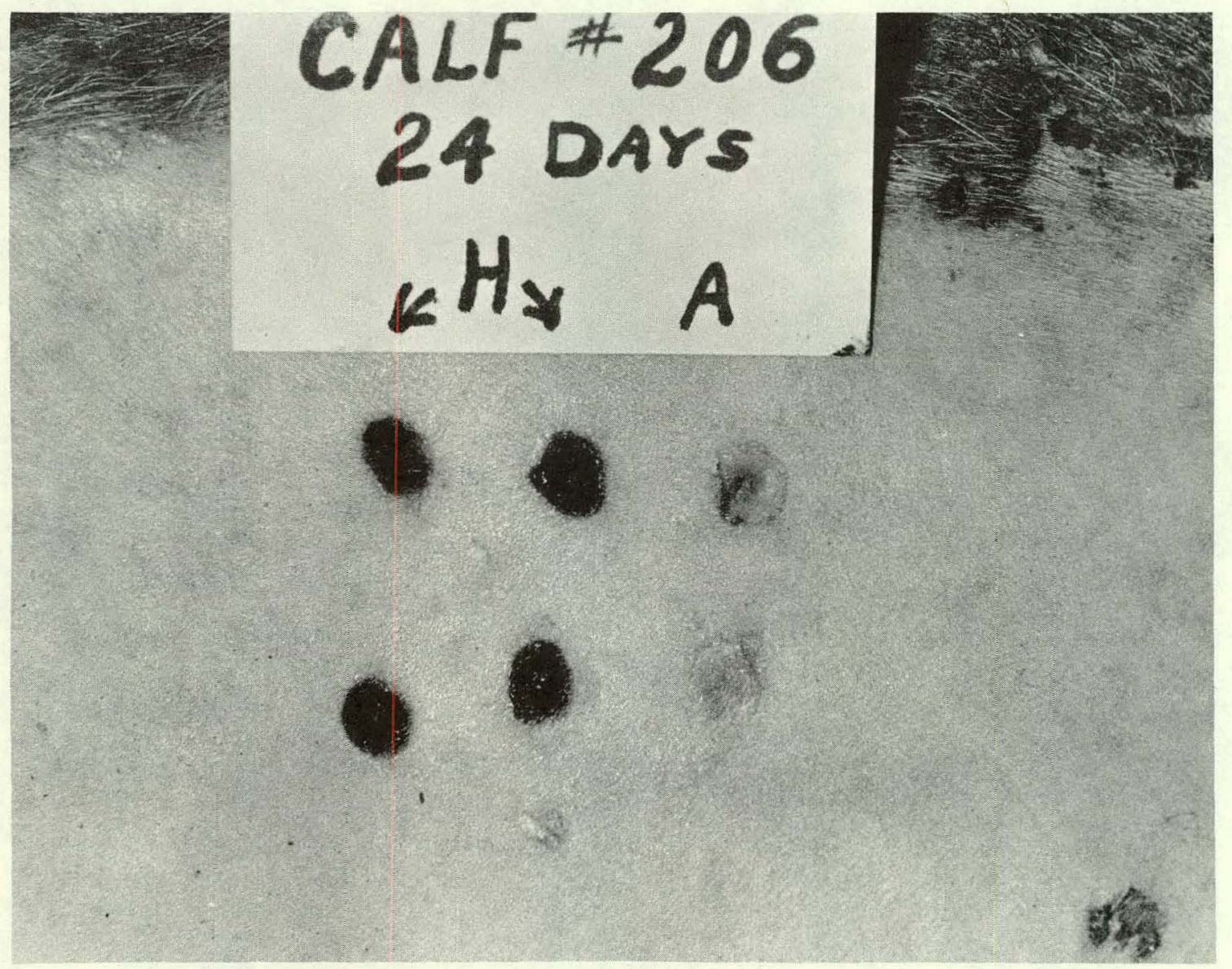

Fit 6 


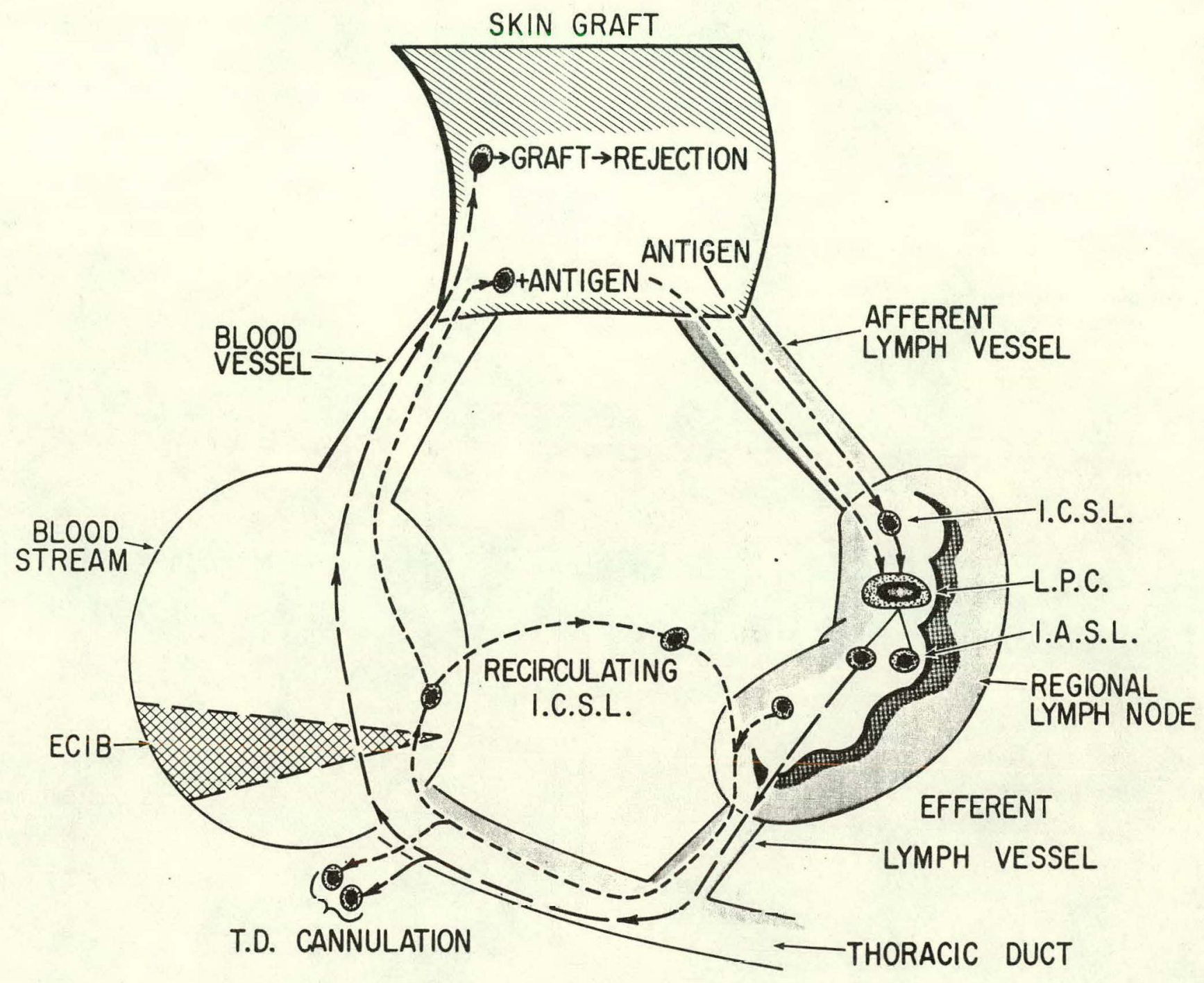

I.C.S.L. = IMMUNOLOGICALLY COMPETENT SMALL LYMPHOCYTES L.P.C. = LARGE PYRININOPHILLIC CELL

I.A.S.L. = IMMUNOLOGICALLY ACTIVATED SMALL LYMPHOCYTES

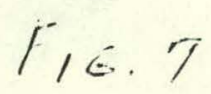

